\title{
Maoist People's War and Community Adaptation: A Case of Community Forest User Groups Nepal
}

\section{- Nirmal Kumar BK*}

* DFID-Livelihoods and Forestry Programme, Nepal

Corresponding author: nirmalkumarbk@gmail.com

Abstract: The ten year long armed conflict between the state and the Maoists in Nepal had tremendous impact on all sectors and communities in the rural area. However, based on the study of three Community Forest User Groups (CFUGs) of Eastern Nepal, it is argued that CFUGs were less vulnerable than other rural institutions. The paper further discusses how CFUGs adapted their coping strategies and functioned more effectively than other village level institutions during the conflict period. It was observed that due to adjustments of the Maoists agendas for CFUGs planning such as issues surrounding poverty reduction, social inclusion and caste/ethnic/gender-based discrimination, the Maoists did not adversely affect inclusion an

Key words: conflict, adaptation, threat, vulnerability, livelihoods

\section{INTRODUCTION}

The people in Nepal suffered a decade long (1996-2006) State-Maoist conflict. The Maoists justified their struggle as to fight political absolutism, social injustice and economic inequity in the country (Pathak 2005). The conflict had tremendous impact from the micro to macro level in the social, economic and political sectors. It affected the everyday life of the people and the country's overall development, leading to a significant decline in state services, including forestry (Banjade and Timsina 2005). About 17000 people were killed and more than 16,719 people internally displaced during the conflict (Rauniyar 2010). Furthermore, infrastructure worth NRs. 5,000 million (equivalent to 71 million U.S. dollar) was destroyed. The people faced terrible threats and increased risks from both the conflict parties. During that time, the people were more vulnerable than ever before in the history of Nepal (Uprety 2006)

The impact of the armed conflict was more intense in rural than urban areas. The Maoists differentiated themselves from classical communists as the strength of Nepal's proletariat lies within the rural peasantry rather than in the urban ruling class (Upreti 2004). More importantly, the Maoists had a remarkable effect on indigenous and rural institutions and their activities of organising people in different sectors. The Community Forest User Groups (CFUGs) and their activities also faced this situation. The rural people, especially those who live in and around the forests and are dependent on the forest resources for their livelihoods, became the immediate victims of the conflict. The CFUGs came under tremendous pressure from the warring parties, viz. the state's security forces (army and police) and the Maoist insurgents (Uprety 2006). However, CFUGs were affected less and were less vulnerable to the conflict than other rural institutions like Village Development Committees (VDC), District Agricultural Office, Range Post and Financial Institutions (Uprety 2006). Therefore, CFUGs functioned more effectively than other village level institutions during the conflict. 
Although, rural People faced risk from conflict, however, they developed their own strategies to cope with these risks. The vulnerability of people in this paper mean a function of its sensitivity (degree of positive or negative effects), adaptive capacity (ability to take advantage of opportunities and to minimise adverse effects) and exposure (condition of being susceptible to adverse effects). Vulnerability is the susceptibility of (i) adverse effects from conflict risks and (ii) the loss of livelihood assets of the CFUGs. It depends upon the characteristics, extend and sensitivity of these conflict risks and the adaptive capacity of CFUGs.

The capacity of adaptation determines its vulnerability. Adaptation means adjustment to actual or expected stimuli and its effects. This was partly possible as most of the local people did not have any other options than to negotiate with the conflicted parties.

\section{METHODOLOGY}

\section{Study Sites and Data Collection}

This is an exploratory study therefore; qualitative methods of data collection were used. The data was collected in the Terhathum district which is situated in the Koshi zone. Three CFUGs: Katike, Pathibhara and Chenchengaddhi were selected for this study. They resemble according to the impact the conflict situation had on them: highly, medium or less affected by the conflict. The selection process followed the technique of a systematic random sampling. Due consideration was also given to the distance of the CFUGs from the district headquarter, as the extend of the impact differed. A formal and informal mode of data collection was applied, such as group discussions, key informant interviews and workshops with district level stakeholders were conducted. Author's working experience in the region also added value on the research design, and writing this article.

\section{RESULT AND DISCUSSION}

The armed conflict had both positive and negative impacts on forestry and natural resource management. Therefore, it was necessary to study the contextual relationship between the conflict and its impact on community forestry. The study analysed how forest management practices were altered by CFUGs under the threats and risks of the conflict.

\section{Increased Risk to CFUGs and Their} Leaders

Maoist conflict has affected all types of community groups since its inception in 1996 However, CFUGs were even more affected after the royal takeover in 2002. Before that the Maoists used to appreciate the community forestry programme saying that it is a community managed programme and includes all sections of rural people and manages the local resources effectively.

When Maoists began to influence the CFUGs after then royal take over, they raised the issue of transparency and accused the leaders for misusing the CFUG funds. As an entry point of influencing the CFUGs, the Maoists started writing letters to the CFUG leaders demanding a donation worth up to $30 \%$ of their total income to support the Maoist people's war. In addition to this, they enforced a tax on all CFUGs who sold their forest products outside their respective community. For example, Kartike CFUG of Sukrabare VDC used to harvest and export resin and catechu and therefore a tax of $5 \%$ was imposed upon their income. The Maoists enforced $5 \%$ regular tax on the income derived from all kinds of forest product exports from the CFUGs.

After the royal takeover the Maoists intensified their movement against the monarchy. They increased mass gatherings of their cadres in the rural area. Instead of taking shelter in the houses 
of the villagers they began to cook for the harvesting of forest products, which themselves. This increased the demand of fuel- ultimately affected the livelihoods of the local wood and created pressure on the CFUGs to supply the needed fuel-wood. CFUGs which denied their demand to give of fire-wood to the Maoist, were threatened to kill. Maoists closed those CFUGs by forbidding activities and seizing CFUG documents, including meeting minutes. For example, Maoists seized the register of Kartike CFUG. It was not only the reason that the Maoist dissatisfied with CFUGs who did not agree in harmony with them, rather they also wanted to show to the state that they can stop the functioning of stateinduced mechanisms in rural areas. To increase their hold in CFUG committees, Maoists pressurised CFUGs leaders and other key person in the village to include them in the decision making body of the CFUG. Since most of the CFUG leaders were belonging to their political parties than the Maoist, and therefore they became more furious towards CFUGs. Time and again they started to pressurise CFUGs by asking for donations and forest products, and in addition threatened and abducted executive committee members. It was found that the Maoists visited the house of the chairperson, secretary and treasurer of Kartike and Pathibhara CFUGs at night time and, threatened them and even abducted them in order to get information about income, decision made and any connectivity with state security forces.

people. Responding to the state declaration, the Maoist had also declared the Pathibhara CFUG as a prohibited zone and banned any activities or movement inside the forest. Forest dependent people who had no ownership over the forest were more exposed to conflict risks than rich people who owner private forests. Forest guards, wood workers, regular fuelwood collectors were regularly confronted by both conflicted parties. Also, there was a risk of encountering ambush and electric shocks set up by both the Maoists and state security forces inside the forest. The frequency of the visits of the forest dependent people reduced to about $40 \%$. In addition to that only $50 \%$ of the normal benefit from the forest products utilisation was derived. Quite regularly members of Pathibhara CFUG returned empty handed from the forests due to sudden visits of the army. Local people were intimietated try security forces because of when they were forced to return back without collecting forest products. More importantly, the poor people faced greater vulnerability to fulfil their forest product needs during the conflict which severely affected their lives and livelihoods.

It was generally noticed that the elite members were more targeted by the Maoists while the poor and excluded members of the CFUGs were under attack from the security forces

Simultaneously, there were risks from the state's security forces to CFUGs, since the community forests were used by the Maoists as training camps and hiding places for their fighters eventually in Kartike and Pathivara, were declared as prohibited areas by the security forces. They further banned Pathibhara CFUG activities for about 10 months without any prior notice. The situation resulted many complexities for example CFUG members could not enter into the forest for management activities like suspecting them of being Maoist supporters. State security forces assumed that most of the poor, dalits and ethnic people gave shelter to Maoists and provided them with information about security mobilisation. It was also alleged that they knew the whereabouts of the Maoists. The security forces often interrogated the poor people about Maoist movements in the village. Also, the insurgent gained support for their activities from the oppressed and so called lower caste in the study area. 
Adaptation Measure Taken to Conflict of a membership fee to please the Maoists. Risks They also stopped the practice of rotational forest protection systems as there was great risk

CFUGs had adopted mixed strategies to cope with actual or expected conflict risks and their impacts. They implemented both proactive (before impact) and reactive (after impact) adjustments and autonomous (spontaneous) or planned modifications through the support of external organisations including the Federation of Community Forestry Users, Nepal (FECOFUN), and the Livelihood and Forestry Program (LFP).

Local CFUG leaders employed different strategies to deal with Maoists. The agenda of inclusiveness in resource allocation for the benefit of the poor and excluded was an instrument to increase their adaptation to war risks. Also, CFUGs have rigorously made and updated their priorities and agendas, such as inclusiveness or livelihood improvement of the poor and excluded, which was acceptable for the Maoists at the local level. In addition, they made policies and institutions that directly supported the poor and excluded members of the groups. Also, they diversified their activities from forestry-focus to people-focus such as programmes for safer motherhoods, revolving funds for the poor or the implementation of small infrastructure activities in remote areas. The pro-poor-friendly activities of the CFUGs increased their negotiation power with the Maoists.

The CFUGs stopped practices that were risky and harmful to them due to the conflict situation and others that did not meet the need of the poor and excluded. They amended the provision of taking high interest rates on loans given by the CFUG, levied collections from the CFUG members and voluntary unpaid labour by the poor members. The Chengchengadi CFUG used to collect monthly NR 5 from its 114 household members but later lifted its policy in entering the forest during the conflict time.

The CFUGs advocated that the community forestry programme was the common property resource management practice where no room for exclusion in membership and benefit distribution exists. Also, CFUG members negotiated with the Maoist highlighting that community forestry promotes a communal concept in managing land and forest resources that directly contributes to the livelihoods of the local people, particularly to the poor, dalits and ethnic people.

Additionally, the CFUGs used poor and ethnic people as messengers and to convince Maoists in creating a common understanding between them about their activities. It was common practice that most of the Maoist cadres took shelter at the houses of poor and excluded members with an aim to convince them to join their war against the state. On the other hand, the CFUG leaders communicated and trained the poor and disadvantaged people about the community forestry programme and how it can contribute to the livelihoods of the local people.

The roles of service providers and FECOFUN were seen positive in the changing political context at that time. The bring focus of all such organisations was to put the poor and disadvantaged people in the driving seat of any intervention initiated by them. District Forest Offices, local NGOs and FECOFUN focused their activities (fund mobilisation, small infrastructure development, cash crop plantation, micro-enterprise development, etc.) towards the poor. Responding to the initiative of allocating a portion of a degraded part of the community forest land to the poor by Kartike CFUG, Maoist allowed the entry of CFUG members inside the community forest which was banned previously. 


\section{CONCLUSION AND} RECOMMENDATION

The people of Nepal suffered from the ten years long (from 1996 -2006) armed struggle between the state and the Maoists, which was more intense in rural areas. However, the study shows that the CFUGs, which have wider coverage in the rural area of the nation in terms of forest resource users, were found less affected by the conflict and were less vulnerable than other rural institutions.

CFUGs adopted mixed strategies to cope with actual or expected conflict risks and its impacts. As the Maoists fought against poverty, discrimination and injustice, the CFUGs changed their behaviours and policies and adjusted their agendas at the local level and communicated with both the security forces and the Maoists for their survival.

\section{REFERENCES}

Banjade, M. \& Timsina, N. 2005 Impact of Armed Conflict in Community Forestry of Nepal, ETFRN News 43(44): 8183.
Dahal, D.R. \& Bhatta, C.R. 2008. "The Relevance of Local Conflict Resolution Mechanisms for Systemic Conflict Transformation in Nepal" Washington University USA. Available at: http://www.berghofpeacesupport.org/publications/ (Accessed on4 November 2009)

Hatlebakk, M. 2009. Explaining Maoist Control and Level of Civil Conflict in Nepal. CMI Bergen, Norway.

Rauniyar, I. 2010"Govt rubs salt into war victims' wound" news published on the Kathmandu Post (TKP 4.11.2010 p4).

Pathak, B. 2005. Politics of People's War and Human Right in Nepal. BIMIPA Publication, Kathmandu.

Robledo, C. \& Forner, C. 2005. Adaptation of forest ecosystem and the forest sector to climate change. Forest and climate change working paper 2, FAO/ SDC, Rome.

Upreti, B.R. 2004. The Price of Neglect: From Resource Conflict to Maoist Insurgency in the Himalayan Kingdom. Bhrikuti Academic Publications.

Uprety, D.R. 2006. Conflicts in Natural Resource Management: Examples from Community Forestry. Available at: www.boku.ac.at/oega. (Accessed on 2009) 